\title{
The Effects of Abdominal Massage on the Management of Constipation: A Systematic Review of Randomised Controlled Trials
}

\author{
Konstipasyonun Yönetiminde Abdominal Masajın Etkisi: Randomize Kontrollü \\ Çalışmaların Sistematik Derlemesi
}

(1) Emel Emine KAYIKÇI1, io Vildan KOCATEPE22, id Ferda AKYÜZ3, id Gülbeyaz CAN33

Iİstanbul Medeniyet University Faculty of Health Sciences, Division of Nursing, İstanbul, Turkey

${ }^{2}$ Acıbadem Mehmet Ali Aydınlar University, Division of Nursing, İstanbul, Turkey

${ }^{3}$ İstanbul University Cerrahpaşa Florence Nightingale Faculty of Nursing, Department of Internal Medicine Nursing, İstanbul, Turkey

\section{ABSTRACT}

This study aimed to assess the effectiveness of abdominal massage in the management of constipation.

We conducted this systematic review by scanning Pubmed, CINAHL, EBSCOhost, ScienceDirect, Ovi, ProQuest, Web of Science and ULAKBIM National Databases without any time restriction. To search the literature, we used the following keywords: "constipation", "constipation management" and "abdominal massage". We included into the systematic review randomised controlled trials on constipation management whose full texts were available both in English and Turkish, while studies without the full text and/or ongoing studies were excluded. A total of 31 articles were found; however, only 9 of these studies met the inclusion criteria.

The effects of abdominal massage on constipation management have been assessed in different randomised controlled trials, with the participation of cancer, parkinson, multiple sclerosis and orthopedics and traumatology patients. The abdominal massage was applied to the patients in the supine position and in the direction of the colon, with different techniques of circular movements (kneading, vibration, effleurage, superficial or deep stroking techniques) for different periods (10-40 minutes) and at different frequencies ( 1 to 2 times in a day or week). In six trials, abdominal massage and laxatives were applied to the experimental group,

\section{Öz}

Çalısmanın amacı konstipasyonun yönetiminde abdominal masajın etkinliğini değerlendirmekti. Sistematik derleme nitelikte olan bu çalışma, yıl sınırlaması olmaksızın, Pubmed, CINAHL, EBSCOhost, ScienceDirect, Ovi, ProQuest, Web of Science, ULAKBİM Ulusal Veri Tabanları taranarak gerçekleştirildi. Literatür taraması "konstipasyon", "konstipasyon yönetimi", "abdominal masaj" anahtar kelimeleri kullanılarak gerçekleştirildi. Çalışmaya konstipasyonun yönetiminde İngilizce ya da Türkçe tam metnine ulaşılabilen randomize kontrollü araştırmalar dahil edildi, tam metin olmayan ve/veya devam eden çalışmalar kapsam dışı bırakıldı. Toplam 31 araştırma makalesine ulaşıldı, bu çalışmaların sadece 9 tanesi araştırmaya dahil edilme kriterlerine uygun olduğu belirlendi. Konstipasyonun yönetiminde abdominal masajının etkisi kanser, parkinson, multiple skleroz ve ortopedi ve travmatoloji hastalarının katılımı ile gerçekleştirilen farklı randomize kontrollü çalışmalarda değerlendirilmiştir. Bu hastalara karın masajı, hasta supine pozisyonunda iken, kolon yönünde dairesel hareketler ile farklı teknikler (yoğurma, vibrasyon, efloraj, yüzeyel veya derin vuruş) kullanılarak, farklı sürelerde (10-40 $\mathrm{dk}$ ), farklı sıklıkta (günlük veya haftada 1-2 kez) yapılmıştır. Altı çalışmada deney grubuna abdominal masaj ve laksatif, kontrol grubuna ise kliniğin standart protokolü (laksatif ve/veya yaşam

Address for Correspondence: Emine Emel KAYIKÇI, İstanbul Medeniyet University Faculty of Health Science, Division of Nursing, İstanbul, Turkey

E-mail: emel.ozdemir@medeniyet.edu.tr ORCID ID: orcid.org/0000-0002-1511-0830

Received: 05.10 .2018

Accepted: 02.02.2020

Cite this article as: Kayıkçı EE, Kocatepe V, Akyüz F, Can G. The Effects of Abdominal Massage on the Management of Constipation: A Systematic Review of Randomised Controlled Trials. Bezmialem Science 2020;8(3):311-7. 
whereas the standard clinical protocol (laxative and/or change in the lifestyle) was applied to the control group. In a study, massage based on the tensegrity principle (balance the tension of muscles, fasciae and ligaments that are structurally associated) was applied to the control group. In another study, the classical abdominal massage was applied to one group, the aroma massage was applied to the second group and only laxatives were administered to the third group. To assess constipation, the Gastrointestinal Symptom Rating scale, Constipation Severity index, Bristol Visual Stool scale, Constipation Quality of Life Questionnaire and Neurogenic Bowel Dysfunction or bowel diary were used in these studies.

Our results showed that abdominal massages were effective in reducing constipation-related symptoms, increasing the frequency of defaecation and enhancing the quality of life of patients.

Keywords: Constipation, constipation management, abdominal massage şekli değişikliği) uygulanmıştır. Bir çalışmada, kontrol grubuna tensegrity ilkesine dayalı masaj (yapısal olarak bağlantılı kas, fasya ve bağların gerginliğini dengeleme) uygulanmıştır. Diğer bir çalışmada ise bir gruba klasik karın masajı, bir gruba aroma masajı, üçüncü gruba ise laksatif uygulanmıştır. Konstipasyonun değerlendirilmesinde ise çalışmalarda Gastrointestinal Semptom Derecelendirme ölçeği, Konstipasyon Şiddeti ölçeği, Bristol Görsel Dışkı ölçeği, Konstipasyon Yaşam Kalitesi ölçeği, Nörojenik Barsak Disfonksiyonu ya da barsak günlüğü kullanılmıştır. Çalışmadan elde edilen sonuçlar, abdominal masajın konstipasyon ilişkili semptomları azaltmada, defekasyon sıklığını arttırmada ve yaşam kalitesini iyileştirmede etkili olduğunu göstermiştir.

Anahtar Sözcükler: Konstipasyon, konstipasyon yönetimi, abdominal masaj

\section{Introduction}

Constipation is currently one of the most common symptoms related to the digestive system. It does not only negatively affect the quality of life, well-being, social life and daily life activities of individuals, but also causes economic losses. Constipation may be idiopathic, although neurogenic or non-neurogenic diseases like irritable bowel syndrome, hypothyroidism, hypocalcemia as well as drugs and pregnancy may play a role in its etiology (1). In addition, changes in the diet, patient exercises, acute emotional stress, abdominal surgery and the disease course are also among the causative factors of constipation $(2,3)$.

In previous studies, the prevalence of constipation has been determined to be between $0.7 \%-79 \%$ across the world, with an average of $16 \%$ and a rate of $35 \%$ in elderly people. It is more frequent in women, elderly people, home care patients and terminal patients (4-6).

Today, pharmacological and non-pharmacological approaches are used in constipation management; however, the pharmacological methods are more frequently used. The most commonly used pharmacological approaches are laxatives, enema and suppositories (7), which leads to an increase in cost. Regarding the non-pharmacological approach, lifestyle changes like diet, fluid intake and increasing physical activity are applied (8). Apart from this, many other non-pharmacological approaches like abdominal massage, meditation, the use of probiotics, biofeedback, reflexology and acupuncture are used (9).

Abdominal massage is one of the non-pharmacological approaches used in the management of constipation. It is a cheap non-invasive method that has no side effects and can be easily applied by patients and their relatives (10). The use of abdominal massage in constipation management dates back before the 1870 s. Abdominal massage is performed by placing the patient in a semiFowler or supine position, applying circular movements in the direction of colon and in the bowel region over the abdominal wall, using kneading, vibration, effleurage and superficial or deep stroking techniques. It has been reported in the literature that abdominal massage increases parasympathetic stimulation, muscle motility, and the release of digestive secretions $(10,11)$. It has also been reported that abdominal massage exerts mechanical and reflexive effects on digestive system organs by enabling the relaxation of the sphincters in the gastrointestinal system. Based on these effects, abdominal massage provides a bowel purge by accelerating gastric emptying and bowel peristalsis (12). There is no review that has evaluated the effectiveness of abdominal massage on constipation management. Therefore, the purpose of this study was to systematically examine scientific evidences regarding the effectiveness of abdominal massage on constipation management.

\section{Method}

This study was a systematic review examining randomised controlled trials that were conducted to determine the efficacy of abdominal massage on constipation management. Two researchers conducted the literature search in Turkish and English by scanning Pubmed, CINAHL, EBSCOhost, ScienceDirect, Ovi, ProQuest, Web of Science and ULAKBIM National Databases, without any time restrictions. The following keywords were used: "constipation", "constipation management", "abdominal massage" and their Turkish translations.

\section{Inclusion and Exclusion Criteria}

Studies on constipation management whose full texts were available both in English and Turkish were included into the systematic review. There was no randomised controlled trial in Turkish that had been conducted on this subject.

Studies without the full texts, ongoing studies, studies conducted in languages other than Turkish and English, qualitative, quantitative, review and case studies were excluded from the systematic review.

\section{Assessing the Quality of the Studies}

The studies were assessed by a researcher in terms of the sample size, study groups, characteristics of the interventions applied, assessment scales and results. In addition, two researchers independently assessed each study using the Jadad scoring system. 
The Jadad Scale is one of the scoring systems that is reported to have the best validity and reliability in the methodological assessment of the quality of randomised controlled trials and is frequently used. The trials were assessed as $0-5$ points in the Jadad scale. This scale consists of a total of 5 questions and using this scale, randomisation, the existence of double-blinding, withdrawing from the study and the exclusion from the study are assessed as " 0 " and " 1 " points. In addition, the appropriateness of the randomisation scheme and an appropriate explanation of the double-blinding method are scored as " +1 " and " -1 ". Table 1 shows the Jadad scores of the studies in the present review (13).

\section{Results}

As a result of the search conducted using the aforementioned keywords, a total of 31 articles were found. Six of the 31 articles found were duplicates and were therefore excluded. The remaining 25 trials were screened according to the inclusion and exclusion criteria, after which 9 randomised controlled trials were retained for the systematic review. The included trials were conducted between 2009-2016 (Figure 1).

In the trials, the patients were classified according to the Rome II and Rome III criteria for constipation developing in cancer, Parkinson, multiple sclerosis, orthopaedics and traumatology patients. The abdominal massage was applied to the patients for constipation management in the supine position and in the direction of the colon, with different types of circular movements (kneading, vibration, effleurage and superficial or deep stroking techniques), for 10-40 minutes and 1 to 2 times a day or week. The abdominal massage was applied by the patients themselves or by healthcare professionals at home, work, or in the clinic

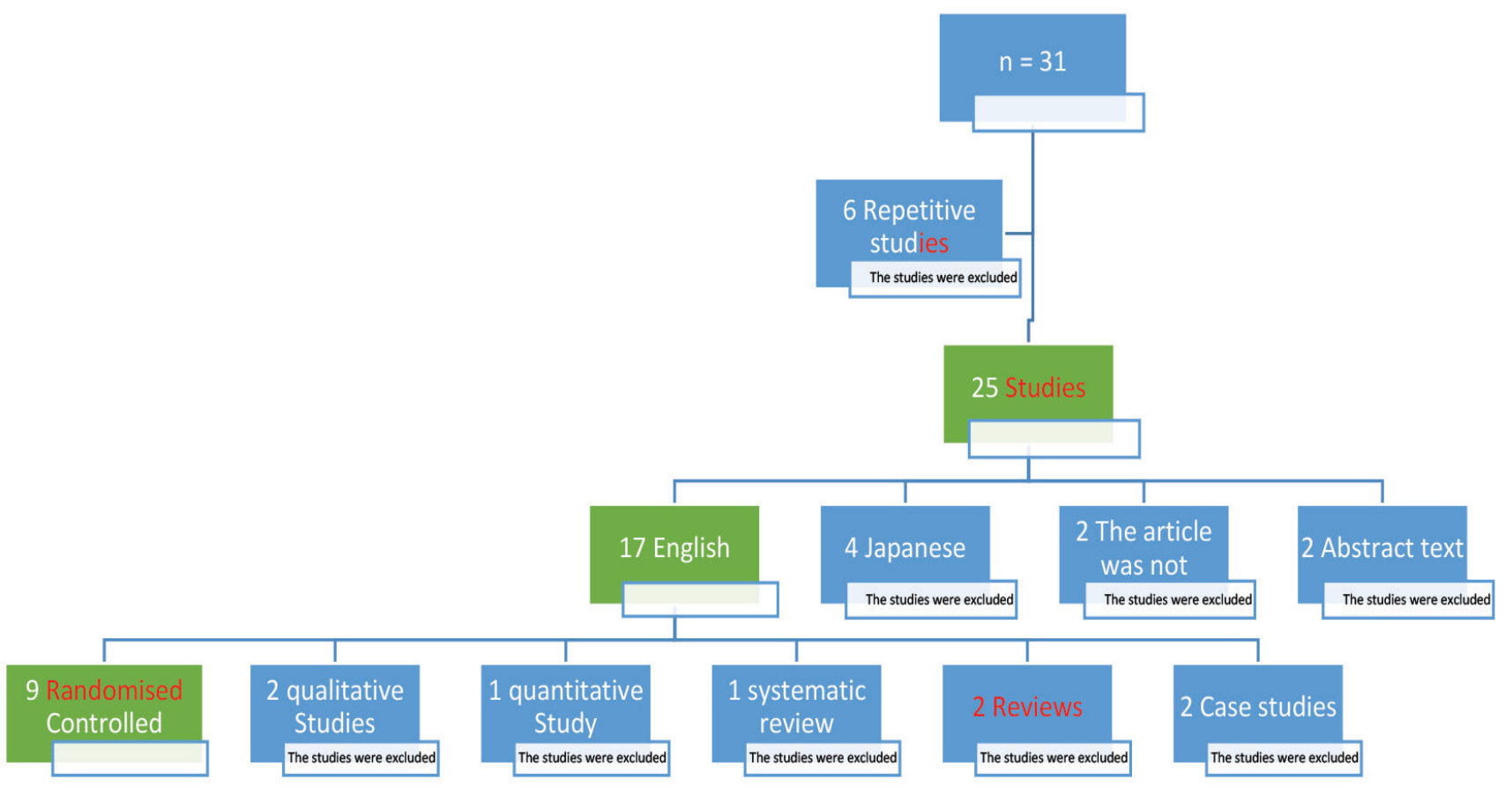

Figure 1. Consort flow chart

Table 1. Jadad Score Assessment-Scoring Criteria

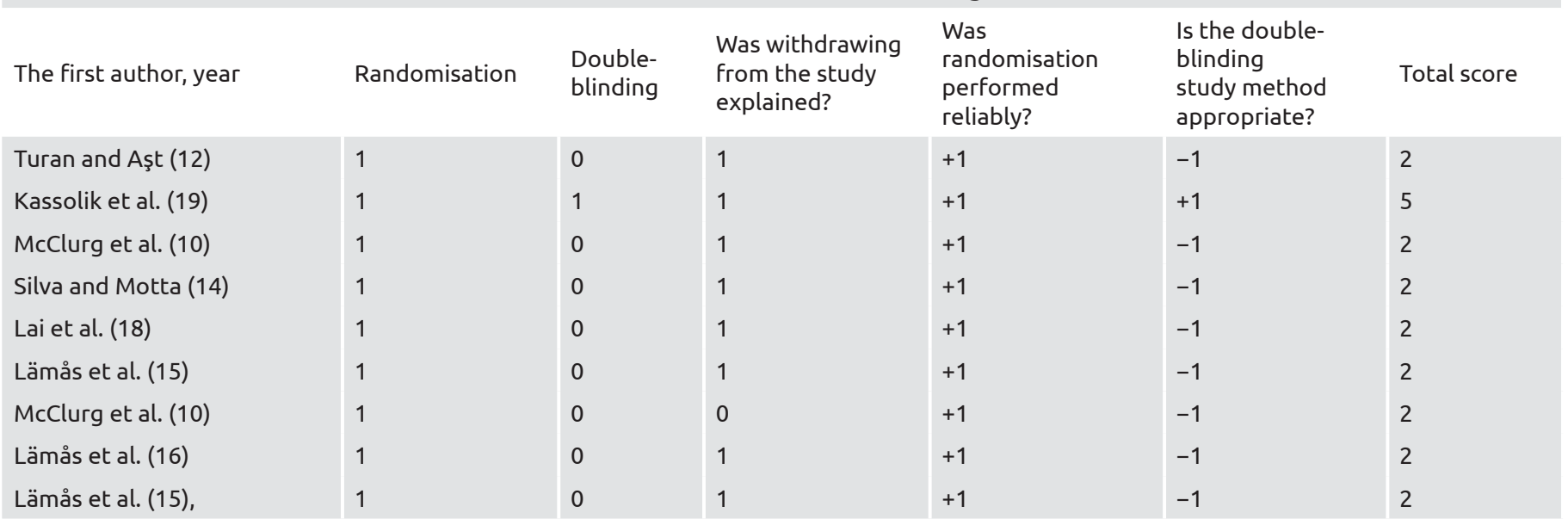


and the patients watched a video of the massage before the application.

In 6 randomised controlled trials, abdominal massage and laxatives were applied to the experimental groups while the standard clinical protocol [laxatives and/or lifestyle change (diet, activity, fluid intake, etc.)] was applied to the control groups. In one study, the tensegrity-based massage was applied to the control group while the classical abdominal massage was applied to the experimental group. In another study, the classical abdominal massage was applied to a group, aroma massage was applied to another group while only laxatives were applied to the third group. Moreover, in another study, abdominal massage, breathing exercises and isometric abdominal muscle training were administered to the experimental group while only laxatives were applied to the control group (Tables 2, 3).

Table 2. The characteristics of the studies included in the systematic review

\begin{tabular}{|c|c|c|c|c|c|c|}
\hline $\begin{array}{l}\text { Study (first } \\
\text { author, year) }\end{array}$ & Aim of the study & $\begin{array}{l}\text { Study } \\
\text { group }\end{array}$ & $\begin{array}{l}\text { Applied } \\
\text { intervention/ } \\
\text { approach }\end{array}$ & Assessment & Conclusion & $\begin{array}{l}\text { Jadad } \\
\text { score } \\
(0-5)\end{array}$ \\
\hline $\begin{array}{l}\text { Turan and } \\
\text { Aşt (12) }\end{array}$ & $\begin{array}{l}\text { To determine the } \\
\text { effect of abdominal } \\
\text { massage on } \\
\text { constipation and the } \\
\text { quality of life in the } \\
\text { orthopaedics and } \\
\text { traumatology patients }\end{array}$ & $E=30$ & $\begin{array}{l}\text { Postop } 4^{\text {th }} \text { day, } 2 \\
\text { times a day for } 3 \\
\text { days, } 15 \text {-minute } \\
\text { abdominal massage } \\
\text { laxative use and } \\
\text { lifestyle change }\end{array}$ & $\begin{array}{l}\text { - Gastrointestinal } \\
\text { Symptom Rating scale, } \\
\text { - Constipation Severity } \\
\text { scale, } \\
\text { - Bristol Visual Stool scale } \\
\text { - The Patient Assessment } \\
\text { of Constipation Quality } \\
\text { of Life (PAC-QOL)scale, } \\
\text { - European Quality of Life } \\
\text { scale (EQ-5D) }\end{array}$ & $\begin{array}{l}\text { It was determined } \\
\text { that the abdominal } \\
\text { massage applied to } \\
\text { the patients diagnosed } \\
\text { with postoperative } \\
\text { constipation reduced the } \\
\text { constipation symptoms, } \\
\text { the time intervals } \\
\text { between defaecations } \\
\text { and enhanced the quality } \\
\text { of life }\end{array}$ & 2 \\
\hline $\begin{array}{l}\text { Kassolik et } \\
\text { al. (19) }\end{array}$ & $\begin{array}{l}\text { To compare the } \\
\text { efficacy of tensegrity- } \\
\text { based massage and } \\
\text { the classical abdominal } \\
\text { massage applied to } \\
\text { constipated patients }\end{array}$ & $C=14$ & $\begin{array}{l}\text { Tensegrity massage } \\
\text { for } 20 \text { minutes, } 2 \\
\text { times a week, for } 21 \\
\text { days } \\
\text { Abdominal massage } \\
\text { for } 10 \text { minutes, } 2 \\
\text { times a week, for } 21 \\
\text { days }\end{array}$ & $\begin{array}{l}\text { - Rome III questionnaire } \\
\text { - Bowel diary }\end{array}$ & $\begin{array}{l}\text { It was observed that the } \\
\text { massage based on the } \\
\text { tensegrity principle had } \\
\text { a more positive effect on } \\
\text { the quality and amount } \\
\text { of bowel movements } \\
\text { compared to the classical } \\
\text { abdominal massage }\end{array}$ & 5 \\
\hline $\begin{array}{l}\text { McClurg et } \\
\text { al. (10) }\end{array}$ & $\begin{array}{l}\text { To reduce the } \\
\text { constipation } \\
\text { symptoms in Parkinson } \\
\text { patients }\end{array}$ & $C=16$ & $\begin{array}{l}\text { abdominal massage } \\
\text { every day for } 6 \\
\text { weeks, } \\
\text { Change of lifestyle }\end{array}$ & $\begin{array}{l}\text { - Gastrointestinal } \\
\text { Symptom Rating Scale } \\
\text { - Constipation Severity } \\
\text { Scale } \\
\text { - Neurogenic Bowel } \\
\text { Dysfunction } \\
\text { - Bowel diary }\end{array}$ & $\begin{array}{l}\text { An abdominal massage } \\
\text { is an effective approach } \\
\text { in Parkinson patients } \\
\text { for the treatment of } \\
\text { constipation }\end{array}$ & 2 \\
\hline Lai et al. (18) & $\begin{array}{l}\text { To examine the effect } \\
\text { of aroma massage } \\
\text { on constipation } \\
\text { in terminal cancer } \\
\text { patients }\end{array}$ & $\begin{array}{l}\text { Aroma } \\
\text { M:13 } \\
\text { Classic } \\
\text { M:11 } \\
\text { C: } 8\end{array}$ & $\begin{array}{l}\text { Aroma M of } 15-20 \\
\text { minutes for } 5 \text { days } \\
\text { Classic Abdominal M } \\
\text { of } 15-20 \text { minutes for } \\
5 \text { days } \\
\text { laxative use and } \\
\text { lifestyle change }\end{array}$ & $\begin{array}{l}\text { - Constipation Rating scale } \\
\text { - Quality of life scale for } \\
\text { Hong Kong (MQoL-HK) }\end{array}$ & $\begin{array}{l}\text { The aroma massage was } \\
\text { found to reduce the } \\
\text { constipation score in the } \\
\text { terminal cancer patients } \\
\text { and to enhance the } \\
\text { quality of life. }\end{array}$ & 2 \\
\hline
\end{tabular}


In the assessment of constipation, the Gastrointestinal Symptom Rating scale, Constipation Severity index, Bristol Visual Stool scale, Constipation Quality of Life scale, Neurogenic Bowel Dysfunction and bowel diary were used.

It was observed by Turan and Aşt (12) that abdominal massage applied for postoperative constipation in orthopaedics and traumatology patients reduced the constipation symptoms and the time intervals between the defaecations, enhancing the quality of life (12).

Previous studies on constipation among parkinson and multiple sclerosis patients stated that abdominal massage was an effective approach $(2,10)$.

On the other hand, among individuals with chronic functional constipation, the muscle training/abdominal massage/diaphragm breathing combination and medical treatment were compared. With the combined use of isometric training of the abdominal muscles, respiratory exercises and abdominal massage, an increase was observed in the defaecation frequency, whereas no change in faecal incontinence was observed. Of note, the above-mentioned studies were of low quality (14).

In the studies conducted by Lämås et al. (15), it was observed in different years that abdominal massage for constipation management reduced the severity of gastrointestinal symptoms, particularly increased bowel movements and reduced laxative intake. In addition, it was determined that abdominal massage was cost-effective in the long term (15-17).

In the study conducted by Lai et al. (18), to examine the effect of aroma massage on constipation in the terminal cancer patients, aroma massage was applied to a group, the classical massage was applied to another group and laxatives and lifestyle change were applied to the control group. It was shown that aroma massage may be used in terminal cancer patients.

In the study with the highest quality among the studies in the present systematic review, the classical abdominal and tensegrity-

Table 3. The characteristics of the studies included in the systematic review

\begin{tabular}{|c|c|c|c|c|c|c|}
\hline $\begin{array}{l}\text { Study (first } \\
\text { author, year) }\end{array}$ & The aim of the study & $\begin{array}{l}\text { The study } \\
\text { group }\end{array}$ & $\begin{array}{l}\text { Applied intervention/ } \\
\text { approach }\end{array}$ & Assessment & Conclusion & $\begin{array}{l}\text { Jadad } \\
\text { score }(0-5)\end{array}$ \\
\hline $\begin{array}{l}\text { Lämås et al. } \\
\text { (16) }\end{array}$ & $\begin{array}{l}\text { To determine the } \\
\text { efficacy of abdominal } \\
\text { massage on constipation } \\
\text { treatment }\end{array}$ & $C=30$ & $\begin{array}{l}\text { abdominal massage for } \\
\text { five days a week, once a } \\
\text { day, } 15 \text { minutes, } 8 \text { weeks } \\
\text { laxatives and Lifestyle } \\
\text { change }\end{array}$ & *Bowel diary & $\begin{array}{l}\text { The Abdominal } \\
\text { massage reduced } \\
\text { the use of laxatives } \\
\text { and it was asserted } \\
\text { that it may be used in } \\
\text { the management of } \\
\text { constipation. }\end{array}$ & 2 \\
\hline $\begin{array}{l}\text { McClurg et al. } \\
\text { (10) }\end{array}$ & $\begin{array}{l}\text { To assess the effect } \\
\text { of abdominal massage } \\
\text { on constipation } \\
\text { management in MS } \\
\text { patients }\end{array}$ & $E=15$ & $\begin{array}{l}\text { Abdominal massage for } \\
15 \text { min daily and } 4 \text { weeks } \\
\text { Change of lifestyle }\end{array}$ & $\begin{array}{l}\text { *Constipation } \\
\text { scoring system } \\
\text { *Neurogenic } \\
\text { bowel } \\
\text { dysfunction } \\
\text { *Bowel diary }\end{array}$ & $\begin{array}{l}\text { The abdominal massage } \\
\text { was found to be } \\
\text { effective in reducing } \\
\text { constipation in MS } \\
\text { patients }\end{array}$ & 2 \\
\hline $\begin{array}{l}\text { Lämås et al. } \\
\text { (15) }\end{array}$ & $\begin{array}{l}\text { The effect of abdominal } \\
\text { massage on laxative } \\
\text { use and gastrointestinal } \\
\text { function in the } \\
\text { constipated people. }\end{array}$ & $C=30$ & $\begin{array}{l}\text { Abdominal Massage } \\
\text { for } 15 \text { minutes } 5 \text { days a } \\
\text { week and } 8 \text { weeks } \\
\text { Laxatives }\end{array}$ & $\begin{array}{l}\text { *Gastrointestinal } \\
\text { Symptom * } \\
\text { Rating scale }\end{array}$ & $\begin{array}{l}\text { It was found that } \\
\text { abdominal massage } \\
\text { reduced the severity } \\
\text { of gastrointestinal } \\
\text { symptoms, especially } \\
\text { constipation and } \\
\text { abdominal pain,and } \\
\text { increased the bowel } \\
\text { movements. No } \\
\text { significant correlation } \\
\text { was found between the } \\
\text { massage and laxative } \\
\text { use }\end{array}$ & 2 \\
\hline
\end{tabular}


based massages were compared. It was observed that tensegritybased massage had a more positive effect on the quality and amount of the bowel movements compared to the classical abdominal massage (19).

\section{Discussion}

Constipation is currently a very important gastrointestinal symptom that is frequently encountered due to several reasons. This systematic review is the first of its kind that focuses on abdominal massage techniques applied for constipation management. All of the randomised controlled trials investigating the efficacy of abdominal massage on constipation management, were included into the present study. The number of relevant studies was limited and the methodological quality of the studies varied

After examining the studies that were included in the systematic review, it was observed that they were heterogeneously distributed in terms of intervention, disease, assessment scales and the study results. All the studies revealed that the use of abdominal massage for constipation management was an effective approach. The studies showed that abdominal massage reduced the severity of gastrointestinal symptoms, increased bowel movements and the frequency of defaecation, reduced constipation symptoms and enhanced the quality of life of the patients $(2,10,12,14,15,17,18)$. They also showed that it was a cost-effective method because it decreased the use of laxatives (16). No side effect was reported in the studies.

In most of the studies included in the review, abdominal massage was performed on the patients in the supine position with circular movements in the direction of the colon $(12,14,15,19)$. There were differences in massage techniques in the studies and the most frequent techniques were kneading, vibration, effleurage and superficial or deep stroking $(12,15,19)$. In the studies, the duration of the massage varied between 10-40 min. Additionally, the frequency of the massage was either daily $(2,10,12,15-18)$ or 1 to 2 times a week $(14,19)$.

The reviewed studies revealed that abdominal massage is usually effective in treating constipation. The study by Turan and Aşt (12) revealed that patients receiving abdominal massage twice a day on post-operative 4, 5 and 6 days for 15 minutes defaecated more frequently in the postoperative period than the control group patients and that there was a statistically significant difference between the groups. In addition, it was found that abdominal massage reduced constipation symptoms, decreased time intervals between defaecations and enhanced the quality of life. Similarly, in the study conducted by McClurg et al. (2); abdominal massage was applied to multiple sclerosis patients for constipation management for 15 min every day for 4 weeks and it was found to be more effective compared to the control group. Also, McClurg et al. (2), applied abdominal massage to Parkinson patients for constipation management every day for 6 weeks and a change of lifestyle was made in the control group. As a result of the study, it was observed that there was a symptomatic recovery in both groups. However, there was no significant difference between the groups (10).

There are 3 different studies by Lämås et al. (15), evaluating the effect of abdominal massage on constipation management. The first study was conducted in 2009 and abdominal massage was applied to patients with constipation for 15 min once a day, for 5 days in a week, for 8 weeks. As a result of the study, it was reported that abdominal massage reduced gastrointestinal symptoms and increased bowel movements; however, it was determined that there was no significant correlation between massage and the use of laxatives (15). In their study which was conducted in 2010, the effect of self-massaging and massage by professionals on cost was evaluated for abdominal massage throughout 16 weeks. It was determined that self-massaging could be cost-effective for constipation management in the long term (16). In their third relevant study conducted in 2011, abdominal massage applied for constipation management reduced the use of laxatives and they stated that it could be an effective approach for constipation management (17).

On the other hand, in the study by Lai et al. (18), aroma massage, classic abdominal massage and laxative-lifestyle change were compared. It was reported that aroma massage reduced the constipation score and increased the quality of life compared to the control and classic abdominal massage (18). Similarly, in the study by Kassolik et al. (19), abdominal massage was compared with tensegrity-based massage and it was shown that tensegritybased massage was more effective in improving the quality of bowel movements and amount of defaecation compared to the classic abdominal massage.

In the study by Silva et al. (14); the combined use of abdominal massage, isometric abdominal muscle training and diaphragm exercises was compared with the use of laxatives in patients with constipation and it was determined that there was an increase in the frequency of defaecation with the combined treatment; whereas, there was no change in faecal incontinence at the end of 6 weeks (14).

In all the studies, not only abdominal massage, but also laxatives were applied in the experimental group; whereas, laxatives and/or lifestyle change were applied in the control group. For constipation management, abdominal massage was used instead of laxatives and this reduced the number of laxatives used, although it is recommended to use both in combination $(2,12,16)$. When the quality of the randomised controlled trials was assessed in the present review, it was observed that most of them were of low quality.

\section{Study Limitations}

The limitation of the study is that it assessed only articles published in English. We did not find any randomised controlled trial published in Turkish that evaluated the effect of abdominal massage on constipation. In addition, all the studies that were found had low quality data and the studies were conducted in different sample groups. 


\section{Conclusion}

Abdominal massage is a cheap method without any side effects, which can easily be applied by the patients themselves, their relatives or other healthcare professionals in environments such as the home, workplace or hospital. The effect of abdominal massage on constipation was evaluated in different studies and it was found to be effective. In the light of these finding, it can be recommended that abdominal massage be regularly applied to patients with constipation. Particularly, patients who have a risk of constipation in the clinics can be taught on how to perform the abdominal massage, in order to prevent the patients from getting constipated and also to enhance their quality of life. In addition, the use of laxatives can be reduced and thus, costeffective care can be provided.

When the Jadad scores of the studies were taken into consideration, it was observed that only one of the studies had a high Jadad score; therefore, it is considered that randomised controlled trials performed with a larger sample of patients including those having a similar diagnosis and receiving a similar treatment in order to determine the efficacy of abdominal massage in constipation management are required.

\section{Ethics}

Peer-review: Internally and externally peer reviewed.

\section{Authorship Contributions}

Concept: E.E.K., V.K., F.A., G.C., Design: E.E.K., V.K., F.A., G.C., Data Collection or Processing: E.E.K., V.K., G.C., Analysis or Interpretation: E.E.K., V.K., F.A., G.C., Literature Search: E.E.K., G.C., Writing: E.E.K., V.K., G.C.

Conflict of Interest: No conflict of interest was declared by the authors.

Financial Disclosure: The authors declared that this study received no financial support.

\section{References}

1. Costilla VC, Foxx-Orenstein AE. Constipation. Understanding Mechanisms and Management. Clin Geriatr Med 2014;30:107-15.

2. McClurg D, Hagen S, Hawkins S, Lowe-Strong A. Abdominal massage for the alleviation of constipation symptoms in people with multiple sclerosis: a randomized controlled feasibility study. Mult Scler 2011;17:223-33.

3. Sinclair M. The use of abdominal massage to treat chronic constipation. J Bodyw Mov Ther 2011;15:436-45.

4. Higgins PDR, Johanson JF. Epidemiology of constipation in North America: a systematic review. Am J Gastroenterol 2004;99:750-9.
5. Suares NC, Ford AC. Prevalence of, and risk factors for, chronic idiopathic constipation in the community: systematic review and meta-analysis. Am J Gastroenterol 2011;106:1582-92.

6. Vazquez Roque M, Bouras EP. Epidemiology and management of chronic constipation in elderly patients. Clin Interv Aging 2015;10:919-30.

7. Tramonte SM, Brand MB, Mulrow CD, Amato MG, O'Keefe ME, Ramirez G. The treatment of chronic constipation in adults. A systematic review. J Gen Intern Med 1997;12:15-24.

8. Wisten A, Messner T. Fruit and fibre (Pajala porridge) in the prevention of constipation. Scand J Caring Sci 2005;19:71-6.

9. Saygılı U, Bicak D, Can G, Basibuyuk M, Ghrayeb I, Meron T, et al. Constipation. In: Can, G, editor. Consensus 2017-EvidenceBased Palliative Care in a Cancer Patient. Istanbul: Nobel Medical Bookstore; 2018.p.87-103.

10. McClurg D, Hagen S, Jamieson K, Dickinson L, Paul L, Cunnington AL. Abdominal massage for the alleviation of symptoms of constipation in people with Parkinson's: a randomised controlled pilot study. Age Ageing 2016;45:299-303.

11. Krassioukov A, Eng JJ, Claxton G, Sakakibara BM, Shum S. Neurogenic bowel management after spinal cord injury: a systematic review of the evidence. Spinal Cord 2010;48:718-33.

12. Turan N, Asst TA. The Effect of Abdominal Massage on Constipation and Quality of Life. Gastroenterol Nurs 2016;39:48-59.

13. Jadad AR, Moore RA, Carroll D, Jenkinson C, Reynolds DJM, Gavaghan DJ, et al. Assessing the quality of reports of randomized clinical trials: Is blinding necessary? Control Clin Trials 1996;17:1-12.

14. Silva CAG, Motta MEFA. The use of abdominal muscle training, breathing exercises and abdominal massage to treat pediatric chronic functional constipation. Colorectal Dis 2013;15:250-5.

15. Lämås K, Lindholm L, Stenlund H, Engström B, Jacobsson C. Effects of abdominal massage in management of constipation--a randomized controlled trial. Int J Nurs Stud 2009;46:759-67.

16. Lämås K, Lindholm L, Engström B, Jacobsson C. Abdominal massage for people with constipation: a cost utility analysis. J Adv Nurs 2010;66:1719-29.

17. Lämås K. Using massage to ease constipation. Nurs Times 2011;107:26-7.

18. Lai TKT, Cheung MC, Lo CK, Ng KL, Fung YH, Tong M, et al. Effectiveness of aroma massage on advanced cancer patients with constipation: a pilot study. Complement Ther Clin Pract 2011;17:3743.

19. Kassolik K, Andrzejewski W, Wilk I, Brzozowski M, Voyce K, Jaworska-Krawiecka E, et al. The effectiveness of massage based on the tensegrity Principle compared with classical abdominal massage performed on patients with constipation. Arch Gerontol Geriatr 2015;61:202-11. 